\title{
THE GEOLOGY AND TECTONIC EVOLUTION OF THE TOCANTINS GRANITE-GREENSTONE TERRANE: ALMAS-DIANÓPOLIS REGION, TOCANTINS STATE, CENTRAL BRAZIL
}

\author{
EMILIO LENINE CARVALHO CATUNDA DA CRUZ* \& RAUL MINAS KUYUMJIAN**
}

\begin{abstract}
RESUMO GEOLOGIA E EVOLUCAO TECTONICA DOS TERRENOS GRANITO-GREENSTONE BELT DE TOCANTINS: REGIAO DE ALMAS-DIAN6POLIS, ESTADO DE TOCANTINS, BRASIL CENTRAL O terrene granito-greenstone do sudeste do Estado do Tocantins e parcialmente recoberto por unidades metassedimentares proterozoicas. Na regiao de Almas-Dianopolis o greenstone belt pode ser subdividido em duas seqiiências de rochas supracrustais. A primeira, denominada Formação Corrego do Paiol, é composta por derrames basalticos de alto-Fe, localmente almofadados, e inclui raros derrames de basaltos komatiiticos. A segunda, denominada Formacao Morro do Carneiro compreende uma seqiiencia monotona de filitos sericfticos com camadas intercaladas de rochas sedimentares clasticas e quimicas. Ambas as seqiidncias foram afetadas por metamorfismo de baixa a média pressao e temperaturas variaveis do facies xisto-verde a anfibolito. $\mathrm{O}$ metamorfismo foi acompanhado por um evento deformacional $\left(D_{n}\right)$ que resultou na verticalizacao dos estratos sedimentares e contatos geologicos. $O$ posicionamento de corpos granitoides acentuou as condi?6es termais prevalecentes durante $\mathrm{D}_{\mathrm{n}}$, como sugerido pelos vetores de troca do anfibolio (substituições de edenita e tschermaquita). Estes granitoides constituem complexes granito-gnaissicos intrusivos nos greenstone belts sin a tardi $\mathrm{D}_{\mathrm{n}}$. Tonalitos, granodioritos, trondhjemitos, quartzo-monzodiorito e quartzo-diorito ricos em anfibolio foram agrupados na Suite 1. Tonalitos, trondhjemitos, granodioritos e monzogranitos com biotita foram agrupados na Suite 2. Ambas as suites sao calci-alcalinas tonalito-trondhjemiticas. Redoes de contato, estilo de deformafao das rochas encaixantes, desenvolvimento de fabrica e diferentes rochas fontes ilustram uma complexa estoria para a formagao dos complexes granito-gnaissicos. Zonas de cisalhamento direcionais $\left(\mathrm{D}_{\mathrm{n}+\mathrm{i}}\right)$ posteriores obliteraram parcialmente as estruturas Dn nos domfnios de greenstone belt, mas seus efeitos foram restritos nos domfnios granito-gnaissicos.
\end{abstract}

Palavras-chave: Terreno granito-greenstone, Tectonica arqueana, Estado do Tocantins, Brasil

\begin{abstract}
The geology of Almas-Dianopolis region consists of a granite-greenstone terrane partially covered by Proterozoic metasedimentary units. The greenstone belt can be subdivided in two sequences. The first sequence, named Corrego do Paiol Formation, is composed of high-Fe basaltic flows, locally pillowed, and includes rare occurrences of komatiitic basalts. The second sequence, named Morro do Carneiro Formation, comprises a monotonous sequence of sericitic phyllites, as well as beds of chemical and clastic sediments. Both sequences were subjected to medium- to low- pressure metamorphism and variable temperatures in greenschist to amphibolite facies (MI). Metamorphism was accompanied by a deformation event $\left(D_{n}\right)$ that resulted in vertical sedimentary strata and contacts. Granitoid emplacement enhanced thermal conditions during $\mathrm{D}_{\mathrm{n}}$ event, as suggested by amphibole exchange vectors - edenite and tschermakite substitutions are dominant. These granitoid bodies form large granite gneiss complexes that intruded the greenstone belts during or at the close of the $\mathrm{D}_{\mathrm{n}}$ event. The granitoids are grouped in two suites: Suite 1 comprises amphibole-bearing tonalite, granodiorite, trondhjemite, quartz-monzodiorite and quartz-diorite; and Suite 2 is composed of tonalite, trondhiemite, granodiorite and monzogranite with biotite. Both suites have calc-alkaline tonalitic-trondhjemitic chemical affinities. Contact relationships, deformation style of wall rocks, fabric development and different source rocks illustrate a complex history of granite-gneiss terrane evolution. Later $D_{n+i}$ strike-slip shear zones partially obliterated $D_{n}$ structural features in the greenstone belts, but their effects were restricted in the granite-gneiss domains.
\end{abstract}

Keywords: Granite-greenstone terrane, Archaean tectonics, Tocantins State, Brazil

INTRODUCTION The granite-greenstone terrane of south-eastern Tocantins State, central Brazil, covers about $7,800 \mathrm{~km}^{2}$. The earliest geological mapping of this terrane was that of Costa et al. (1976) and Correia Filho \& Sa (1980), who regarded the region as composed of greenstone-type linear volcano-sedimentary belts. In the years following these publications there has been little additional study in the region, with the exception of Padilha (1984) and Silva et al. (1990) who aimed at establishing some of the geological controls of gold mineralization reported from the Almas-Dianopolis area. This terrane has not yet been formally defined. Our proposal is that the whole region should be called the Tocantins Granite-Greenstone Terrane. A systematic programme of study including stratigraphy, petrology and whole rock chemistry of the lithologic units over an area of approximately $830 \mathrm{~km}^{2}$, was recently undertaken by the first author of this paper and incorporated in his M.Sc. thesis (Cruz 1993). In this paper an attempt is made to outline the geological history of the region with special attention given to the contrast between granite- gneiss complexes and greenstone belt evolution and their contact relationships.

REGIONAL GEOLOGY Initially the Tocantins terrane had been included in the Goias Massif (Berbert 1980; Almeida et al. 1981 ;Danni et al. 1982), which constitutes an internal massif between the Sao Francisco Craton and Brasilia Fold Belt to the east and Guapore Craton and Araguaia Fold Belt to the west (Fig. 1). Recent geochronology-based research has indicated that the Goias Massif, at first thought as Archean in age, includes Neoproterozoic arc-related terranes (Pimentel \& Fuck 1987, Pimentel at al., 1993). The Goias Massif is divided into three crustal blocks separated by gravimetric lows (Hasui \& Haralyi 1985, Costa at al. 1991). The westernmost block includes the Tocantins terrane, with its northern part being partially covered by the Proterozoic Bambui and Natividade groups. Available Rb-Sr and K-Ar data indicate an Archean-Paleoproterozoic age for granitic and gneissic rocks with partial isotopic resetting during the Neo-

* Companhia de Pesquisa de Recursos Minerals - Av. Pasteur n_404, Urea, CEP.: 22290-040, Rio de Janeiro-RJ, Brasil, -Tel. (021) 295-6247 - FAX (021) 295-6347, e-mail: elcruz@guarany.cpd.unb.br or diarmi@cristal.cprm.gov.br

** Institute de Geociencias, Universidade de Brasilia -Campus Universitario, Asa Norte, CEP 70910-900, Brasilia-DF, Brasil, - Tel. (061) 348-2864 - FAX (061) 347-4062, e-mail: raulmk@guarany.cpd.unb.br 


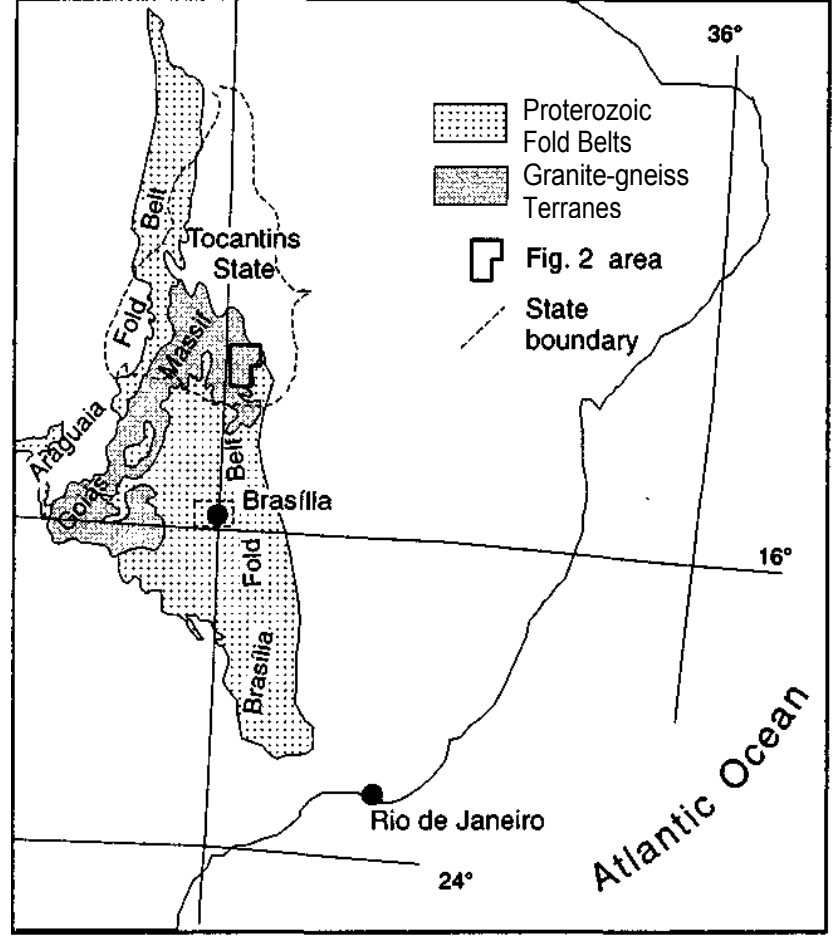

Figure 1 - Summary of the main geotectonic units of central Brazil. Adapted from Almeida et al. (1981)

Figura 1 - Sfntese das principals unidades geotectonicas do Brasil Central. Adaptado de Almeida et al. (1981).

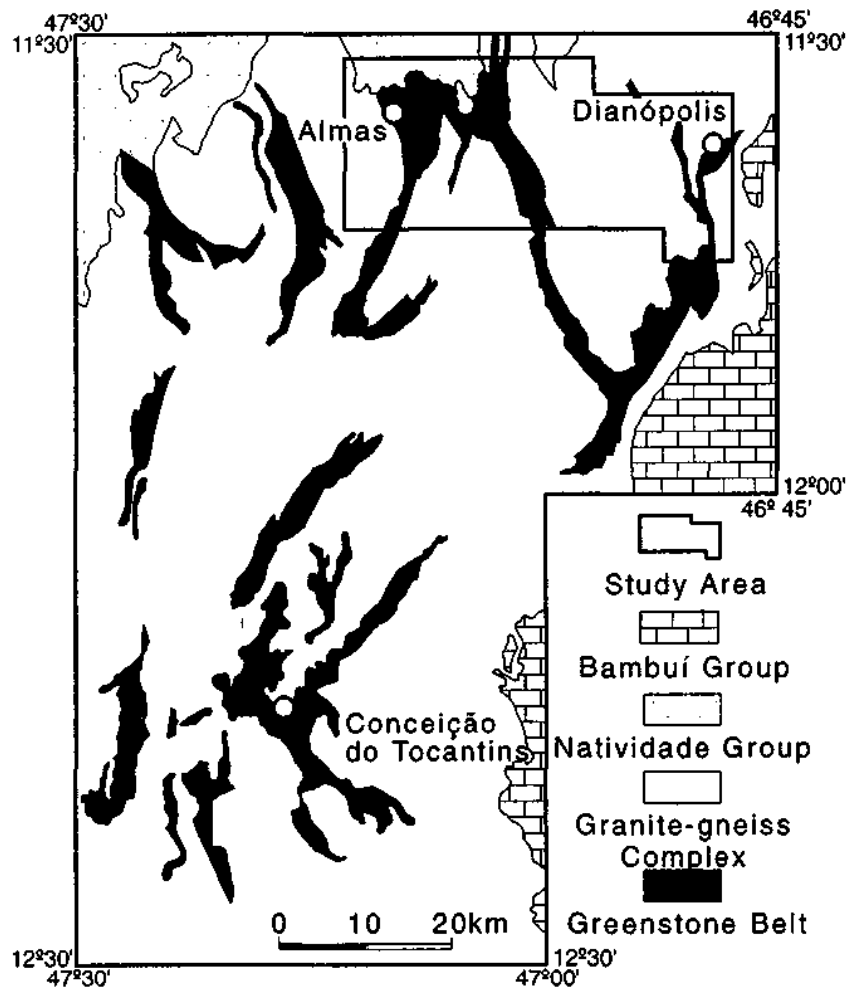

Figure 2 - Simplified geological map of Tocantins granitegreenstone terrane (after Padilha 1984).

Figura 2 - Mapa geologico simplificado dos terrenes granito-greenstone de Tocantins (segundo Padilha 1984). proterozoic Brazilian-Pan-African Cycle (Hasui et al. 1980, Tassinari et al. 1981). This western block corresponds to the western edge of the Sao Francisco Craton reworked during the Neoproterozoic (Almeida 1981, Cruz \& Kuyumjian 1993).

\section{ALMAS-DIANOPOLIS REGION STRATIGRAPHY}

The Tocantins terrane comprises several narrow greenstone belts surrounded by granite-gneiss complexes (Fig.2). The supracrustal greenstone sequence was named the Riachao do Ouro Group by Costa (1984). We retain this name for the complete greenstone sequence, but in addition we also propose to call the lower volcano-dominated unit the Corrego do Paiol Formation and the upper sedimentary unit the Morro do Carneiro Formation. These designations will be used throughout this paper. The original stratigraphic relationship between the two formations is not preserved in the study area due to the vertical position of sedimentary layers and complicating factors of faulting and folding, besides there is nowhere continuity of outcrop, and it is thus not possible to provide anything other than an approximate account of the stratigraphic column. Nevertheless, former workers (Correia Filho \& Sa 1980, Costa 1984) placed Corrego do Paiol Formation at the bottom of the greenstone sequence, and since those authors studied a broader area their column will be maintained for the study area. Over $70 \%$ of rocks exposed are granitoids that occur in large granite-gneiss complexes between the greenstone belts. Costa (1984) obtained $\mathrm{Rb}-\mathrm{Sr}$ ages of $2,050 \pm 276$ m.a. and 2,217 \pm 85 m.a. to a tonalite west to Almas. Contact between these complexes and greenstone belts is either intrusive or faulted. Intrusive basic to ultrabasic rocks occur everywhere, range in size from small metre-scale stocks to $3 \mathrm{~km}$ wide plutons, and embody units of gabbros, pyroxenites, and hornblendites. Correia Filho \& Sa (1980) proposed a Paleoproterozoic age for these intrusions. These Precambrian lithologic units are crosscut by Phanerozoic mafic dike swarms (Fig. 3).

Greenstone belt The lower Corrego do Paiol Formation is composed of dominant metabasalts, locally pillowed (Fig. 4 ), and rare small occurrences of ultramafic metavolcanic rocks. The metabasalts are essentially massive dark green fine-grained amphibole-plagioclase-chlorite-epidote schists. Moreover, at contacts with granitoids actinolite schists are present, probably as a result of contact metamorphism. Ultramafic rocks are tremolite-chlorite schists that crop out near Dianopolis. In a previous paper (Cruz \& Kuyumjiam 1996), an attempt was made to interpret metabasalt whole-rock chemistry. These metabasalts correspond to high-Fe tholeiites. The ultramafic volcanic rocks are high-Mg tholeiites with komatiitic affinity. The pillowed metabasalts are indicative of an underwater flow. The upper Morro do Carneiro Formation consists mainly of a monotonous sequence of sericitic phyllites with carbonaceous material rich layers and more rarely chlorite-bearing layers. It also includes beds of variable thickness of more abundant hematite-magnetite banded iron formations; quartzites with magnetite bearing layers; tourmaline quartzites; and metacherts. Felsic tuffs are exposed near the contact with the Corrego do Paiol Formation south of Almas.

Granite-gneiss Complexes Granite-gneiss complexes consist of weakly foliated granitoid plutons with local gneissic banding. Tonalite, trondhjemite and granodiorite are dominant units (Fig. 5), which characterize the granite-gneiss complexes as TTG-like terranes. Mafic mineral abundance allows us to group these plutons into two suites: i) Suite 1 is amphibole-bearing and ii) Suite 2 is mafic mineral poor, biotite being dominant. The predominance of tonalite, trondhjemite e granodiorite units suggests that both suites 


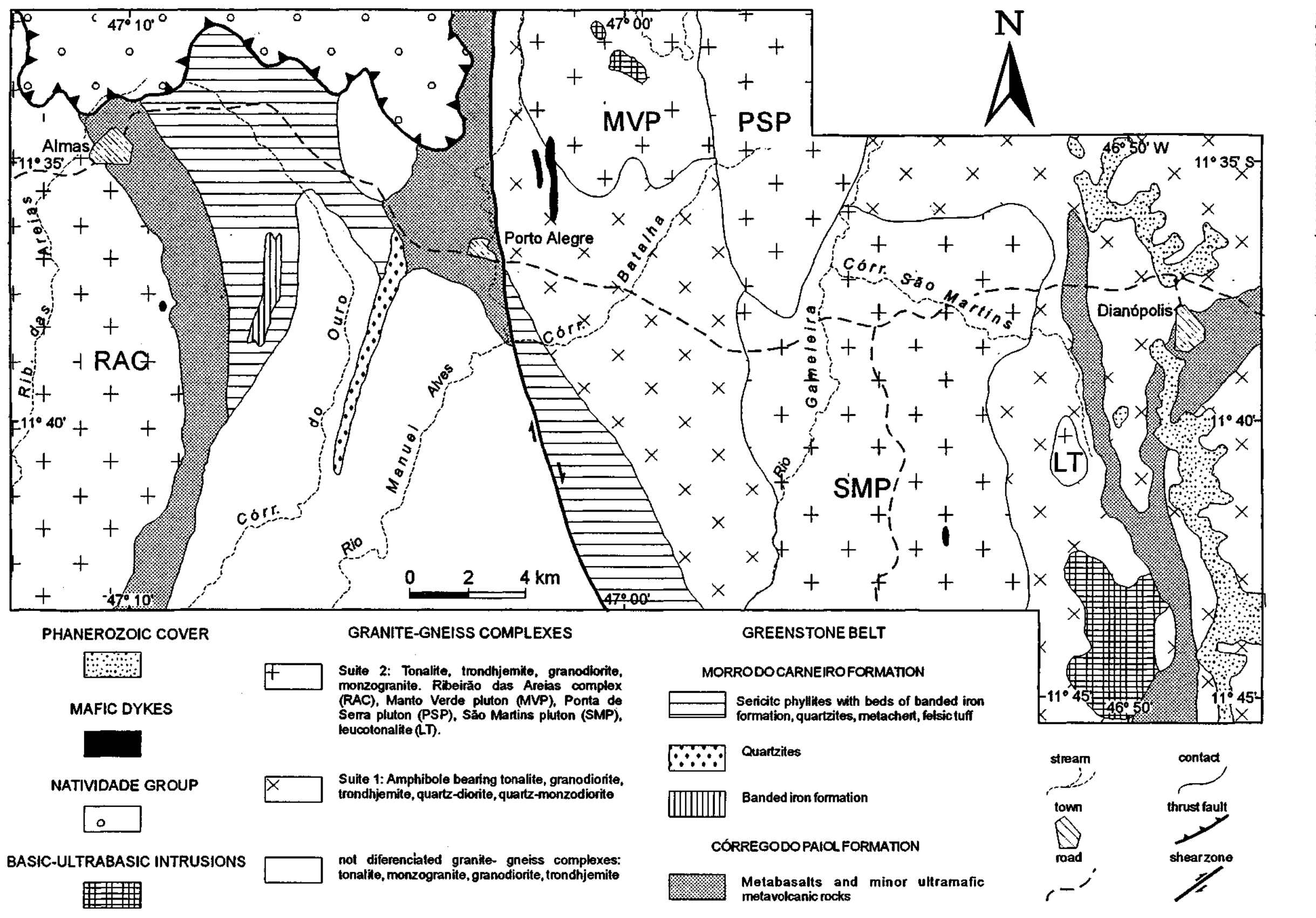




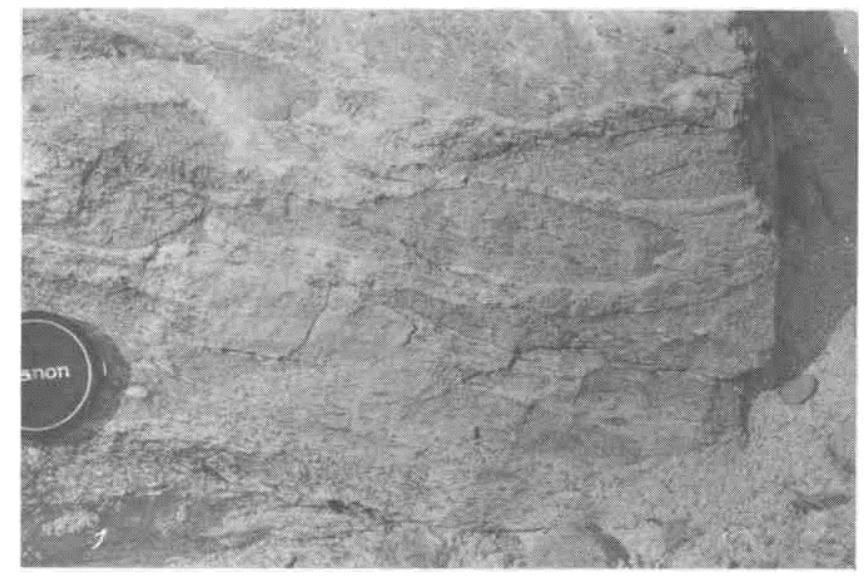

Albite

Figure 4 - Deformed pillowed structures in metabasalt. Figura 4 - Estrutura em almofada deformada em metabasalto.

Orthoclase

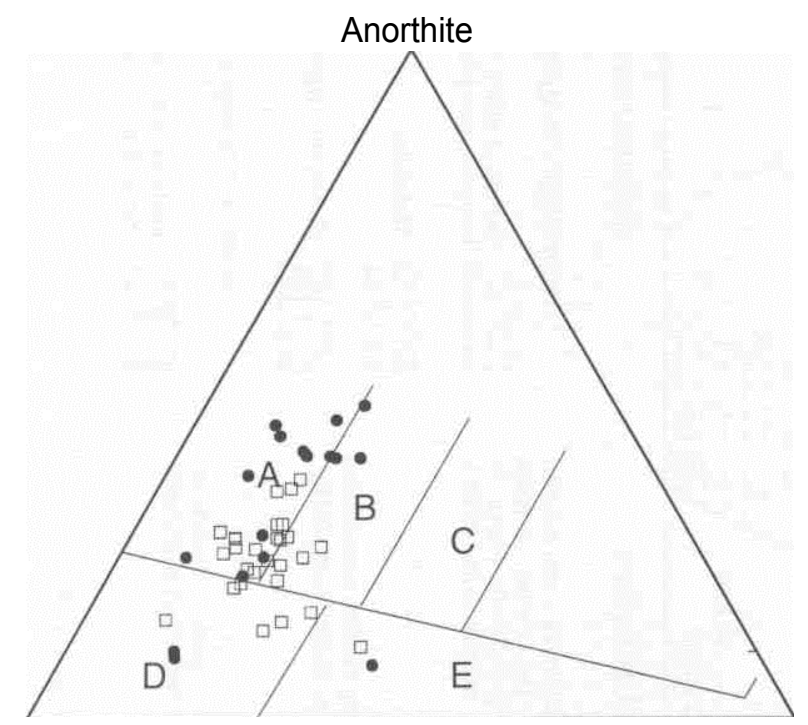

Figure 5 - Normative albite-anorthite-orthoclase diagram (O'Connors 1965). $A=$ tonalite; $B=$ granodiorite; $C=$ adamellite; $D$ = trondhjemite; $E$ - granite. Symbols: Suite 1 (filled circles); Suite 2 (empty squares).

Figura 5 - Diagrama albita-anortita-ortoclasio normativos (O'Connors 1965). $\mathrm{A}=$ tonalito; $\mathrm{B}=$ granodiorito; $\mathrm{C}=$ adamelito; $\mathrm{D}=$ trondhjemito; $\mathrm{E}=$ granito; Sfmbolos: Suite 1 (circulos cheios); Suite 2 - quadrados.

have calc-alkaline tonalite-trondhjemitic affinities. For further details of whole-rock chemistry of the two suites the reader should refer to Cruz \& Kuyumjian (1996). In this previous paper suites 1 e 2 were classified as low- and high-Al TTG suites, respectively. The low $\mathrm{La} / \mathrm{Yb}$ and $\mathrm{Sr} / \mathrm{Y}$ ratios e and high $\mathrm{Ni}, \mathrm{Cr}$ and $\mathrm{Mg}$ enrichment of Suite 1 were interpreted as indicative of an ultramafic mantle source, while the high $\mathrm{La} / \mathrm{Yb}$ and $\mathrm{Sr} / \mathrm{Y}$ ratios, $\mathrm{Yb}$ and $\mathrm{Y}$ depletion of Suite 2 resulted of partial melting of metabasalts (Cruz \& Kuyumjian 1996).

SUITE 1 Amphibole bearing granitoids are exposed in the central and eastern parts of the study area. In the eastern part, amphibole granitoids are equigranular, isotropic to weakly foliated, medium grained, and light grey with scattered dark green amphibole spots and common amphibole clots. Tonalite is dominant, but they also embody amounts of granodiorite, trondhjemite, quartz-monzodiorite and quartz-diorite. The main primary minerals are euhedral mantled plagioclase (40$48 \%$ ), interstitial quartz $(27-40 \%)$, amphibole $(5-15 \%)$, and poikilitic K-feldpars (0-2\%). Accessory phases are apatite, zircon and opaque minerals. Fine grained greyish monzogranite dikes crosscut the latter units. In the central part, amphibole granitoids are tonalite to quartz-diorite with gneissic banding marked by amphibole schlieren. They are medium grained, equigranular and light grey, and include metre-scale layers of dark green medium grained amphibolite. Their fabric becomes more gneissic towards the western contact with the greenstone belt. The main primary minerals are anhedral to subhedral plagioclase $(45-55 \%)$, quartz (25$39 \%$ ) and amphibole (8-15\%) with apatite, zircon and opaque minerals as accessories. A common feature is alteration of plagioclase to epidote group minerals and white mica. Pennine $(5-8 \%)$ is present as result of amphibole alteration. Both the central and eastern occurrences have similar mineral compositions, hence they are regarded as equivalent and belonging to the same igneous suite.

SUITE 2 In central part of the area Suite 2 encompasses Manto Verde, Ponta da Serra and Sao Martins plutons and a small leucotonalite stock. West of Almas the Corrego da Areias Complex crops out. The mafic mineral present is biotite, but in some of the plutons it is rare.

The Sao Martins pluton consists of coarse- to mediumgrained, equigranular greyish-white tonalite and granodiorite. Plagioclase and K-feldspar phenocrysts are common. These granitoids are composed of euhedral to anhedral plagioclase $(41-53 \%)$, quartz $(40-44 \%)$, biotite $(3-15 \%)$, white mica (0$3 \%$ ) and poikilitic K-feldspar (0-4\%). Typical accessory minerals are apatite, zircon and opaque minerals. The eastern part of the pluton includes amphibole-chlorite-plagioclase enclaves, while its western part encompasses biotite rich enclaves (Fig. 6). Equally important, the western part is more foliated than the eastern.

The Ponta da Serra pluton comprises medium-grained, isotropic, equigranular light grey tonalites and granodiorites composed of subhedral plagioclase $(37-55 \%)$, quartz (45$55 \%)$, biotite $(4-7 \%)$ and orthoclase $(0-4 \%)$. Zircon and apatite are common accessory minerals, and white mica, epidote and actinolite occur as products of alteration. Irregular dykelike Ponta da Serra tonalitic-granodioritic intrusions crosscut Sao Martins pluton near the contact.

The leucotonalite is a $2 \mathrm{~km}$ long stock of medium-grained, equigranular, weakly foliated, biotite-poor light grey tonalite intrusive into amphibole granitoids. This stock includes amphibole granitoid xenoliths. Along the contact, amphibole granitoids are crosscut by irregular dikes of leucotonalite.

The Manto Verde pluton consists of isotropic, equigranular, medium-grained, light grey tonalite, trondhjemite and granodiorite with a lesser extent of monzogranite. In the monzogranite K-feldspar phenocrysts are up to $1 \mathrm{~cm}$ long. Plagioclase $(33-38 \%)$, quartz $(40-45 \%)$, orthoclase $(5-25 \%)$, biotite $(1-12 \%)$ and hornblende $(0-4 \%)$ are the main primary minerals, while zircon, apatite and opaque minerals are the common acessories. White mica and epidote are present as plagioclase alteration products. Small amphibolitic enclaves occur along the border of the pluton (Fig. 7).

The Ribeirao das Areias complex comprises medium- to coarse-grained, equigranular, weakly foliated, white-withlight-green-tones trondhjemite which embodies units of tonalite and granodiorite. Foliation becames more intense towards the contact with the greenstone belt. The primary minerals are anhedral to subhedral plagioclase (40-47\%), some of the crystals being euhedral; quartz (35-47\%), with undulose extinction; rare biotite $(0-2 \%)$; and poikilitic to 


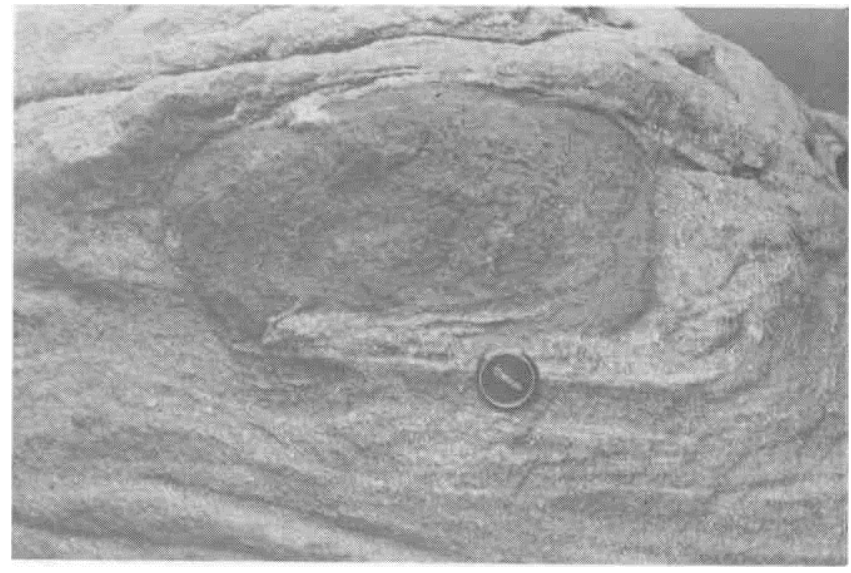

Firuge 6 - Foliated tonalite of São Martins pluton with biotite rich enclave.

Figura 6 - Tonalito foliado do pluton Sao Martins com enclave rico em biotita.

interstitial microcline. Accessory minerals are titanite, zircon and allanite. White mica, actinolite, chlorite and epidote are alteration minerals. These granitoids incorporate xenoliths of mafic greenstone units and locally, of amphibole granitoids. To the south of Almas and Porto Alegre towns there are two granite-gneiss complexes separated by a mylonite zone. Although these two complexes have not been studied in detail, preliminary mapping has shown that tonalite and monzogranite are present in the westernmost complex, and tonalite, trondhjemite and granodiorite predominate in the easternmost complex. Plagioclase (45-60\%), quartz (23$33 \%)$, orthoclase $(5-20 \%)$, microcline $(0-20 \%)$ and biotite $(5-10 \%)$ are the dominant primary minerals. Zircon, apatite and opaque minerals are the accessory phases.

STRUCTURAL GEOLOGY The most significant structural feature is the map geometry of greenstone belts and intervening granite-gneiss complexes. As already recognized by Costa et al. (1976), greenstone belts have a Y shaped map geometry. These belts are mainly linear NE oriented with NW trending cuspate outlines. Curved contacts contouring granite-gneiss complexes are also present. The latter are roughly ellipsoidal. This framework is present from map to outcrop scale (Fig. 8) and, in our opinion, is related to granitoid emplacement. In this section, an attempt is made to contrast structural framework of greenstone belts and granite-gneiss complexes. Regional structures are grouped as early structures related to the $D_{n}$ event and later strike-slip shear zones, related to the $\mathrm{D}_{\mathrm{n}}+\mathrm{i}$ event.

In greenstone domains, early $D_{n}$ structures are a flat schistosity $\left(\mathrm{S}_{\mathrm{n}}\right)$ with local shearing features, upright vertical folds, and mineral lineation $\left(\mathrm{L}_{\mathrm{n}}\right)$. $\mathrm{S}_{\mathrm{n}}$ has subvertical dip, is dominantly NS striking, and tends to be parallel to greenstone belt contacts. $L_{n}$ is nearly horizontal, north or southward dipping. Folds are rare, most of them being centimetre-scale with vertical axis. Sedimentary banding, in sericitic phyllites for instance, is parallel to $S_{n}$ as are the sedimentary contacts. At fold hinges, where $S_{n}$ is oblique to So, an older foliation $\left(S_{n-1}\right)$ parallel to $\mathrm{Sn}$. This older foliation was only seen in sericitic phyllites rich in carbonaceous material. It may be either a diagenetic or tectonic foliation.

Plutons of suites 1 and 2 have the same structural pattern. Toward greenstone contacts foliation tends to intensify, however it is not an ubiquitous feature. Some of granitoids are foliated away from greenstone contacts. In addition, at some of the contacts granitoids are only faintly foliated. This folia- tion is marked by recrystallized quartz and plagioclase crystals and is parallel to $S_{n}$ at contacts with greenstone belts. From this we infer that granitoid intrusion is related to $D_{n}$. In accordance with this intrusions, granitoid apophyses are intruded along $\mathrm{S}_{\mathrm{n}}$ planes.

$\mathrm{D}_{\mathrm{n}+1}$ shear zones are nearly parallel to greenstone belt contacts, have a dextral movement, dip steeply eastward or westward, and strike N20-30 E. Some dextral shear zones have $\mathrm{NO}-10^{\circ} \mathrm{E}$ or $\mathrm{N} 10-20^{\circ} \mathrm{W}$ orientation and are interpreted as subsidiary directions of the $\mathrm{D}_{\mathrm{n}+1}$ event. These shear zones bend from one direction to another. Associated stretching lineation $\left(\mathrm{Lx}_{\mathrm{n}+1}\right)$ dips moderately either north or southward. In granite-gneiss domains $D_{n+1}$ deformation is restricted to the proximity of shear zones, away from them granitoids are not deformed. In greenstone domains there is a development of a penetrative $S_{n+1}$ mylonitic foliation that partially overprints early structures. Parallelism makes difficult a clear field distinction between $S_{n}$ and $S_{n+1}$. These shear zones do not modify to a great extent the broad geometry of the granitegreenstone terrane. The $\mathrm{Dn}+\mathrm{i}$ event is undefined in time. It may have taken place between the end of granite-greenstone terrane evolution and Neoproterozoic. Overlying Natividade and Bambui groups are not affected by $\mathrm{D}_{n+1}$ shear zones, but this may be a consequense of contrasting competence between metasedimentary cover and basement rocks. The extent of Neoproterozoic tectonic events, registered in the cover and effects in the basement rocks is exemplified by $\mathrm{Rb}-\mathrm{Sr}$ system resetting in amphibolites (Hasui et al. 1980).

METAMORPHISM This section is concerned mainly with the metamorphic conditions of metabasalts and is based on amphibole chemistry. Metasedimentary rocks were not useful due to the lack of reliable metamorphic mineral associations. Mineral analyses were made with a CAMECA SX250 electron-microprobe. Textural analysis and spot selection were performed in backscattered electron mode. Quantitative analyses were performed in wavelength distribution system mode. The electron beam diameter was $4 \mathrm{um}$ at $15 \mathrm{kV}$ accelerating voltage and $30 \mathrm{nA}$ sample current. Amphibole nomenclature follows the convention of Leake (1978). Pressure and temperature estimations were made with a internally consistent thermodynamic data set (THERMOCALC version 2.0, Powell \& Holland 1988, Holland \& Powell 1991).

Two metamorphic events are recognised. The first (Ml) relates to the $D_{n}$ event and is restricted to greenstone belts. The second (M2) is related to $D_{n+1}$ shear zones and affects all granitoid-greenstone terrane units. Regional Ml metamorphic assemblages span amphibolite to greenschist-facies. The main regional assemblage is amphibole + plagioclase \pm chlorite \pm epidote. This assemblage is common to pressures from 2 to $10 \mathrm{kbars}$ and temperatures from $250^{\circ}$ to $600^{\circ} \mathrm{C}$ (Thompson et al. 1982). Amphibolites that are included in the western amphibole granitoids outcrops have the assemblage amphibole + plagioclase \pm quartz, which has its lower and upper thermal limits at $550^{\circ} \mathrm{C}$ (after Liou et al. 1974) and $775^{\circ} \mathrm{C}$ (after Spear 1981), respectively. However, the quartz saturation may lower the stability of hornblende as much as $50^{\circ} \mathrm{C}$ (Spear 1981). Close to $D_{n+1}$ shear zones plagioclase breaks down to albite, white mica, and a new epidote generation. The resulting M2 assemblage is amphibole+albite+epidote \pm white mica \pm chlorite.

In amphibole-plagioclase-chlorite-epidote schist, $\mathrm{Ml}$ amphibole composition ranges from ferric actinolite to tschermakitic hornblende, plagioclase is albite $\left(\mathrm{Ano}_{-}\right)$(Table 1). Ferric hornblende is the main amphibole in amphibolites and plagioclase is andesine $\left(\mathrm{An}_{41-48}\right)$. Laird \& Albee (1981) proposed that study of chemical exchange vectors in amphiboles may be useful to understanding metamorphic facies series in Vermont, USA. According to them glaucophane exchange is 


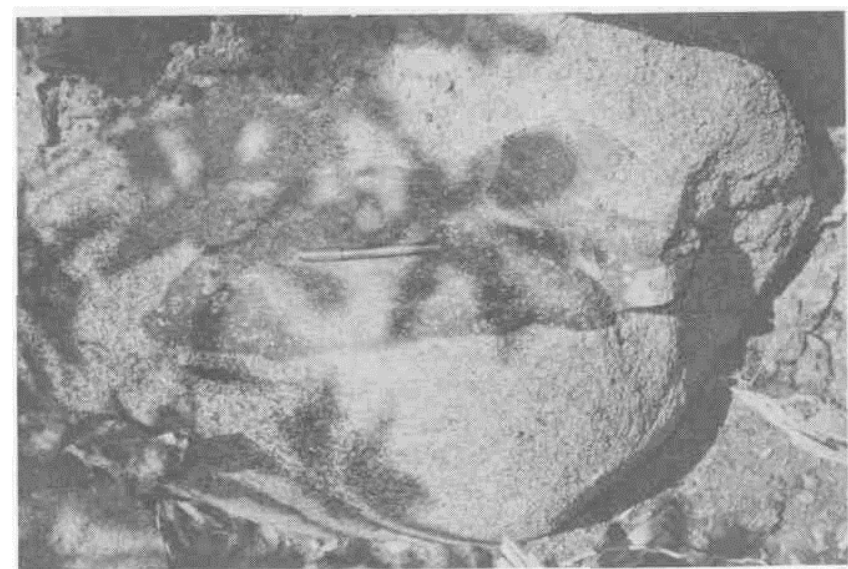

Figure 7 - Isotropic tonalite of Manto Verde pluton with amphibolite enclave.

Figura 7-Tonal iio Notropo do pluton Manto Verde com enclave dean fibolito

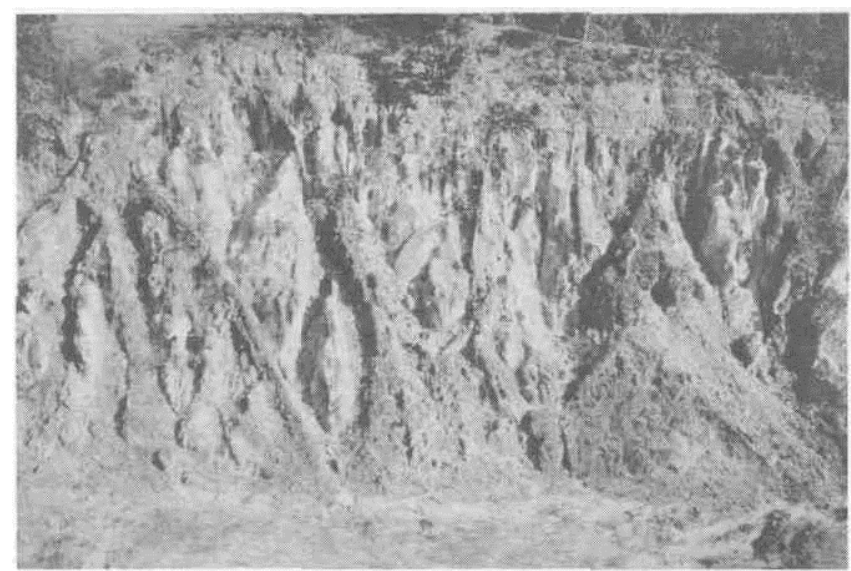

Figure 8 - Outcrop of metabasalts intruded by granitoid bodies along foliation planes

Figura 8 - Afloramento de metabasalto intrudido por corpos de granitoides ao longo da foliação.

dominant in high pressure metamorphic series and edenite and tschermakite exchanges are dominant in low pressure metamorphic series. Amphibole analyses plotted against substitution diagrams proposed by Laird \& Albee (1981) align on low pressure trends (Fig. 9). In a Mengel \& Rivers (1991) substitution diagram amphibole analyses plot on a line that joins tremolite, edenite and tshermakite (Fig. 10). From these diagrams we suggest that tschermak and edenite exchange vectors, both temperature dependent, were dominant in the amphibole crystal chemistry.

THERMOCALC runs performed on two Ml amphibole-plagioclase-chlorite-epidote schist samples gave temperatures of $576 \pm 46$ and $632 \pm 60^{\circ} \mathrm{C}$ and pressures of $3.9 \pm 2$ and $4.4 \pm 2,3$ kbars respectively. M2 estimates were taken from a granitoid of Sao Martins pluton, a hornblende gabbro intrusive in Manto Verde Pluton, and retrometamorphic amphibolite. Temperatures range from $485 \pm 18$ to $539 \pm 65^{\circ} \mathrm{C}$ and pressures from $4.0 \pm 0,2$ to $4.4 \pm 0,5$ kbars. Amphibole analysis were also performed on Manto Verde pluton, the only one with amphibole igneous composition preserved. In this sample neither hornblende, plagioclase or biotite have petrographic evidence of
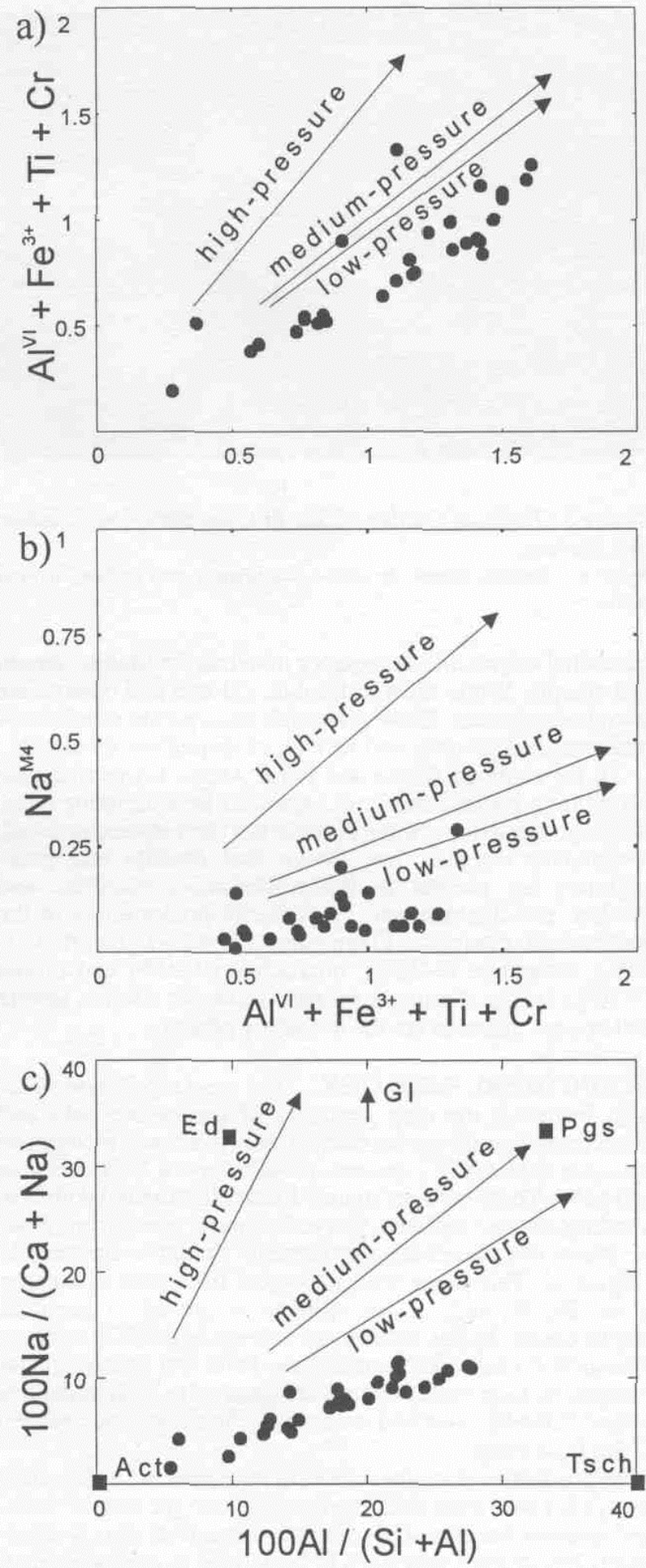

Figure 9 - Formula proportion diagrams for electron microprobe analyses of amphibole related to Ml. Arrows indicate metamorphic series of Vermont (Laird \& Albee 1981). Endmember amphibole composition are indicated (filled squares) in Fig. 6c. Act = actinolite; $E d=$ edenite; $G l=$ glaucophane; Pgs - pargasite; Tsch - tschermakite

Figura 9 - Diagrama de proposes moleculares de analises de anfibolio relacionado a Ml obtidas por microssonda. As setas indicam as series metamorficas Vermont (Laird \& Albee 1981). A composic.ao dos membros extremes de amfibolio estao indicados (quadrados cheios) na figura 6c. Act $=$ actinolita $; \mathrm{Ed}=$ edenita; $\mathrm{Gl}=$ glaucophano; $\mathrm{Pgs}=$ pargasita $; \mathrm{Tsch}=$ tschermakita 
alteration. Amphibole $\mathrm{A} 1^{\mathrm{T}}$ values vary from 0.96 to 1.35 , common in shallow granitic intrusions (Hammarstrom \& Zen 1986). Pressures ranging from 3.6 to $5.4 \pm 0.5 \mathrm{kbars}$ were obtained from the barometer based on $\mathrm{A}^{\mathrm{T}}$ proposed by Johnson \& Rutherford (1989) for igneous pressures. Thus, amphibole igneous composition and pressure estimates imply that Manto Verde pluton is a shallow to intermediate crustal level intrusion.

THERMOCALC calculated pressures and temperatures are shown against some mineral equilibria curves and low and intermediate pressure metamorphic series trend in Figure 11. Ml estimates plot near the low pressure metamorphic series trend within amphibolite facies field, while M2 assemblages tend towards an intermediate pressure metamorphic trend within the epidote-amphibolite facies field. Despite belonging to different rock types, M2 assemblages cluster near to the kyanite-andalusite-sillimanite triple point and therefore M2 metamorphic conditions are equal over the study area and these affected all terrane units. In contrast, petrographic description of sericitic schists, probably of greenschist facies and variable amphibole composition in metabasalts suggest that
$\mathrm{Ml}$ conditions have varied across greenstone belts. It is not clear yet if high temperature assemblages are related to granitoid proximity. Overprinted $\mathrm{D}_{\mathrm{n}+1}$ structures and $\mathrm{M} 2$ assemblages have obliterated Ml map geometry. Nevertheless, concordance of low pressure THERMOCALC Ml estimates, metabasalt amphibole trends and Manto Verde Pluton shallow emplacement indicate that the thermal budget to M1 may have been supplied by granitoid intrusions.

DISCUSSION As mentioned, the greenstone belt is poorly exposed in Almas-Dianopolis region and as a consequence, drawing a complete depositional or igneous geologic history for this supracrustal sequence is not feasable at the moment. The lower Corrego do Paiol Formation would correspond to a sequence of high-Fe tholeitic flows with subordinate high-Mg komatiitic basalts, that have been extruded in a underwater environment. Although, this does not imply that it was an ocean floor setting. Some of the upper Morro do Carneiro Formation sedimentary rocks were deposited under quiet tectonic conditions, i.e. banded iron formation, metachert and carbonaceous material-rich phyllite, and probably also the monotonous sequence of sericitic phyllites.

Table 1 - Representative mineral composition ofmetabasalts. $H b=$ hornblende, Act $=$ actinolite, $P I=$ plagioclase, Ep $=e p i d o t e$, Chl $=$ chlorite.

Tabela 1 - Composifao mineral representativa de metabasaltos. $\mathrm{Hb}=$ hornblenda, $\mathrm{Act}=$ actinolita, $\mathrm{PI}=$ plagioclasio, Ep = epidoto, $\mathrm{Chl}=\mathrm{clorita}$.

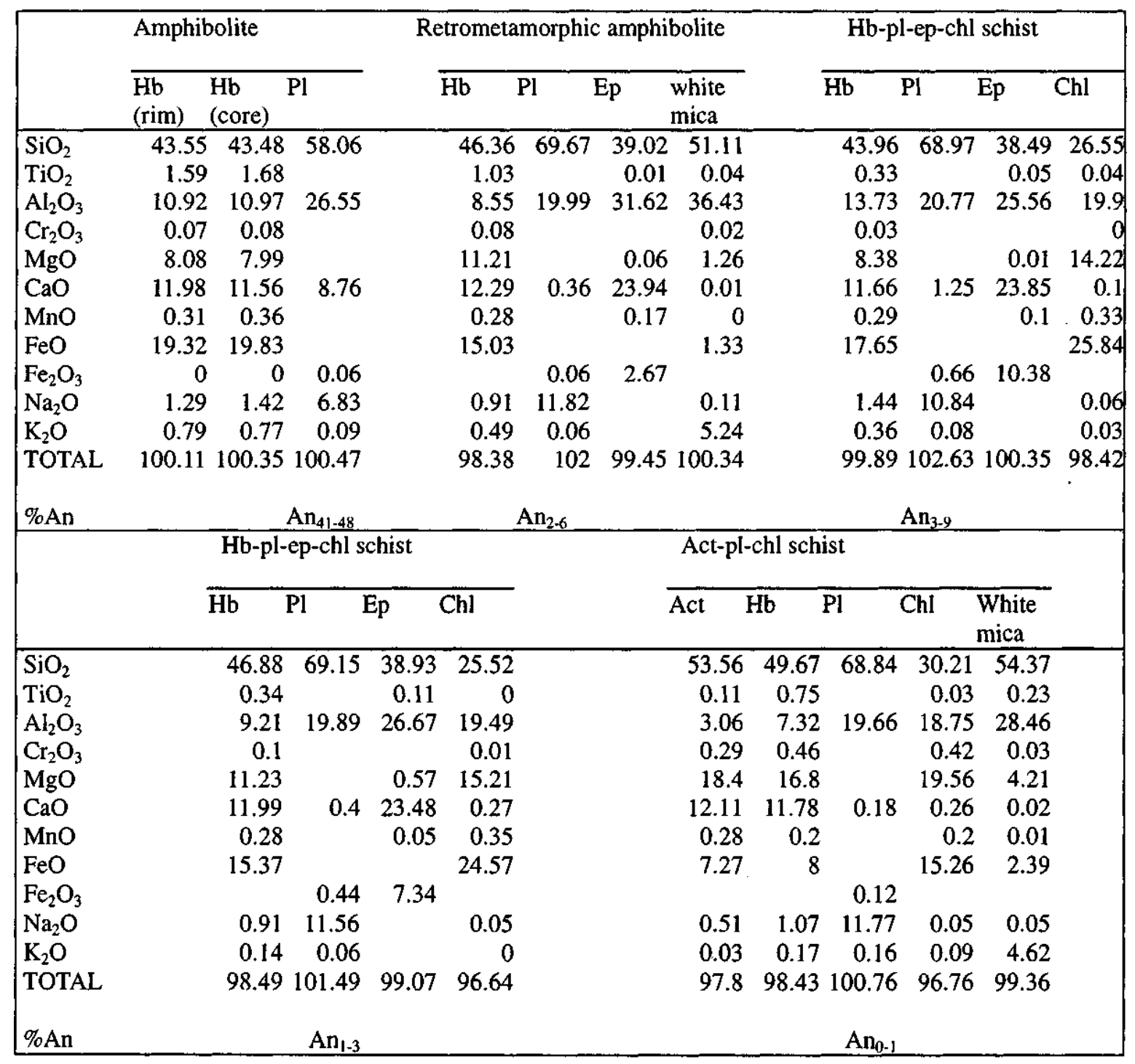




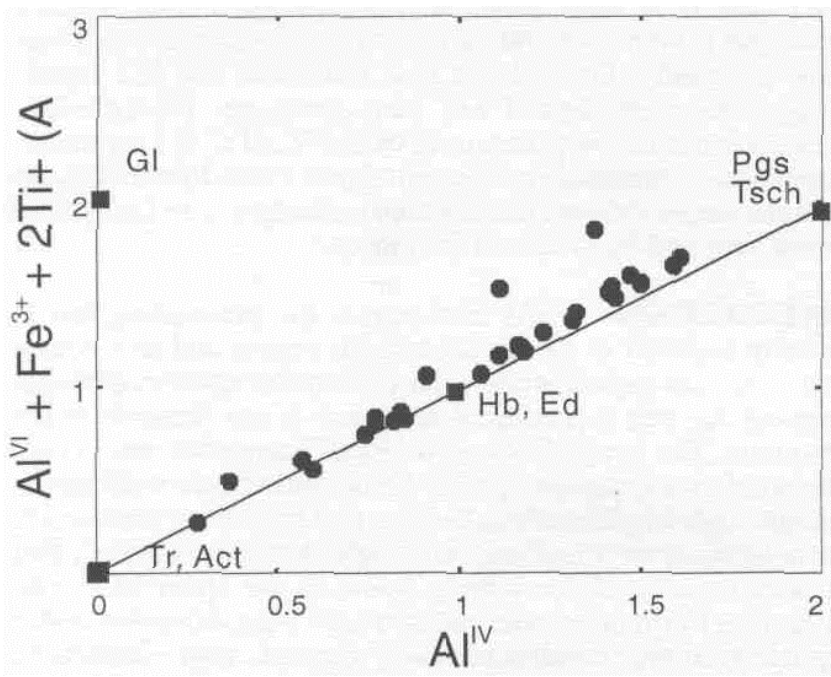

Figure 10 - Formula proportion diagram (Mengel \& Rivers 1991) for electron microprobe analyses ofamphibole related to M1. Endtnember amphibole composition are indicated (filled squares): Act = actinolite; $E d=$ edenite; $G l=$ glaucophane; Pgs - pargasite; $T r=$ tremolite $;$ Tsch = tschermakite Figura 10 - Diagrama de proporcoes moleculares (Mengel \& Rivers 1991) de analises de anfibolio relacionado a Ml obtidas por microssonda eletrônica. A composição dos membros extremes estao indicados (quadrados cheios). Act $=$ actinolita; $\mathrm{Ed}=$ edenita; $\mathrm{Gl}=$ glaucophano; $\mathrm{Pgs}=$ pargasita; $\mathrm{Tr}=$ tremolita; Tsch $=$ tschermakita.

South of the study area, Correia Filho \& Sa (1980) described conglomerates that we are currently including in the Morro do Carneiro Formation.

Most of the granite-gneiss complexes are well exposed and because of that it is possible to establish their internal arrangement. They are intrusive into greenstone belts, as indicated by xenoliths of metabasalts and apophyses that crosscut greenstone rocks. Foliation patterns vary among the plutons, some are faintly foliated or isotropic, others tend to be foliated toward margins, and a few of them exhibit local gneissic banding. Undeformed igneous texture expressed by euhedral to subhedral plagioclase, amphibole, biotite and undulose interstitial quartz reflect igneous primary textures. Even the more foliated portions only show quartz recrystallization and plagioclase alignment. Evidence of shearing or migmatization features are not observed either in granitoids or in greenstone rocks near contacts. The only feature observed is the presence of actinolite schists, a possible metasomatic rock. These field data rule out diapirism as a dominant process in granitoid emplacement. Furthermore, different source rocks to the two suites leads to a more complicated construction of these complexes. Suite 1 results from metabasalt partial melting and Suite 2 has a mantle source (Cruz \& Kuyumjian 1996). It can be suggested that the granite-gneiss terranes represent complexes of multiple intrusion rather than diapiric domes.

The relationship between emplacement of granite-gneiss complexes and the $\mathrm{D}_{\mathrm{n}}$ event is unclear. At this point of our research we propose two possibilities: i) The ascent of granitoids was responsible for the folding and flattening of volcanosedimentary beds; and ii) large volumes of granitoids were intruded along $S_{n}$ planes during or late in the $D_{n}$ event, separating the greenstone sequence into narrow linear belts The first possibility is more typical of diapiric emplacement and would be represented by radial lineations and concentric foliations inside complexes with strong deformation at con-

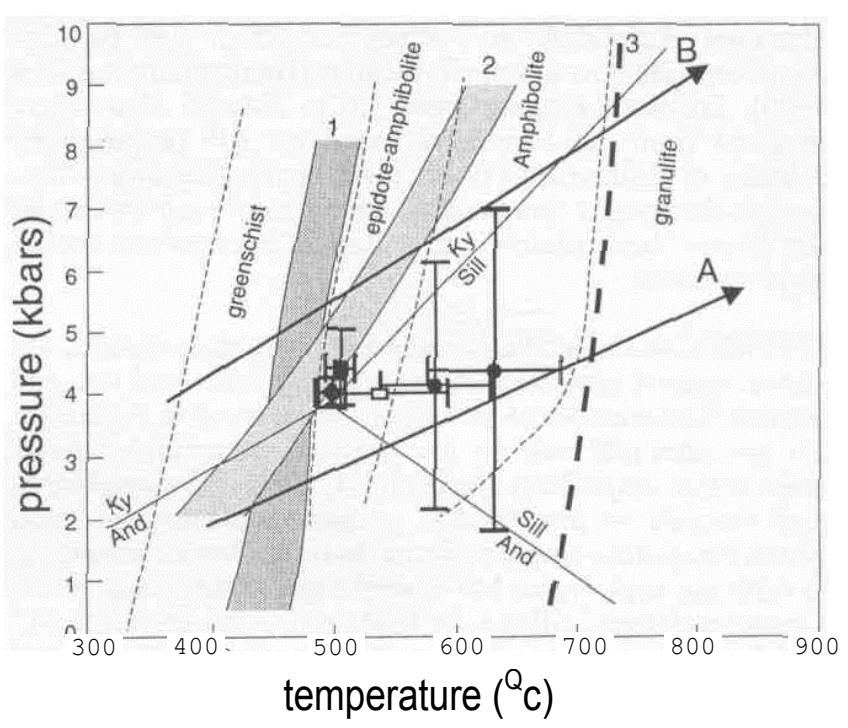

Figure 11 - P-T diagram. Curve 1: actinolite hornblende (from Barker 1990). Curve 2: zone of 2-plagioclases (Mauyama et al. 1983). Curve 3: pyroxene (hyperstene)-in, hornblende-out (from Barker 1990). Arrow indicate metamorphic low (A) and medium (B) fades series trends from Miyashiro (1973). Ky-And-Sill triple point ofHoldaway \& Mukhopadyay (1993). Sample symbols: amphibole-plagioclaseepidote-chlorite schists (filled circles); granitoid (filled square); hornblende gabbro (filled diamond); and, retrometamorphic amphibolite (empty square; no pressure estmative). The three later samples represent M2 P-T condition. The first represent M2 P-T conditions. Error is indicated by bars.

Figura 11 - Diagrama P-T. Curva 1: actinolita- hornblenda (de Barker 1990). Curva 2: zona de 2 plagioclasios (Mauyama et al. 1983). Curva 3: piroxenio (hiperstenio)-entra, hornblenda-sai (de Barker 1990). Seta indica a serie de fades metamorfico baixo (A) e medio (B) de Miyashiro (1973). Ky-And-Sill ponto trfplice de Holdaway \& Mukhopadyay (1993). Sfmbolo das amostras: amfibolio-plagioclasio-epidoto-clorita schistos (cfrculos cheios); granitoides (quadrados cheios); hornblenda gabro (diamantes cheios) e anfibolito retrometamorfico (quadrado vaado, sem estimativa de pressao). As ultimas tres amostras representam conduces de P-T de M2. A primeira representa as condifoes de P-T de M2. Erros indicados por barras.

tacts (Shackleton 1995, Kisters \& Anhaeusser 1995). As indicated before, these features are not prominent, although a weak foliation be parallel to contacts of these complexes. The second possibility would account for the variable degree of deformation of granitoid plutons and of foliated contact rocks, i.e. actinolite schists. Ml thermobarometric estimates and amphibole chemistry agree with simultaneity between the two events, both of low to intermediate pressures. Intrusion of a large volume of grantitic magma would have enhanced thermal gradient prevalent during $D_{n}$ and would have been responsible for the observed low pressure trends. Absence of prominent contact metamorphic rocks implies that the temperature contrast between granitoids and greenstones was not high.

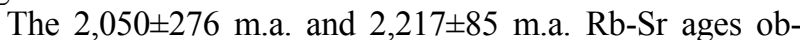
tained by Costa (1984) give a minimum age for granitoid emplacement and the $\mathrm{D}_{\mathrm{n}}$ event, placing the construction of granite-gneissic complexes at the Archaean-Paleoproterozoic boundary. The later $\mathrm{D}_{\mathrm{n}+1}$ event and associated metamorphism (M2) has its time interval still poorly constrained. It may correspond to the latest manifestation of the Archaean-Paleoproterozoic granite-greenstone terrane evolution or result of 
further influence of Proterozoic tectonic events, e. g. Brazilian Cycle.

CONCLUSIONS 1) In the Almas-Dianopolis region, the Tocantins granite-greenstone terrane is comprised of a volcano-sedimentary sequence intruded by large complexes of granite-gneissic rocks.

2) The lower Corrego do Paiol Formation is composed of high-Fe tholeitiic basalt flows with local outcrops of high-Mg komatiitic basalts. The upper Morro do Carneiro Formation is mostly a monotonous sequence of sericitic phyllites which includes beds of chemical and clastic sedimentary rocks.

3) Granite-gneiss complexes consist of two suites of granitoid bodies. Suite 1 is composed of amphibole-rich granitoids, mainly tonalite and granodiorite with units of trondhjemite, quartz-diorite and quartz-monzodiorite. Suite 2 consists mostly of tonalite, trondhjemite and granodiorite, but monzogranite units occur locally. This suite includes xenoliths of amphibole granitoids. Whole rock chemistry indicates that Suite 1 granitic magmas were derived by partial melting of mantle and Suite 2 plutons resulted from partial melting of a basaltic source (Cruz \& Kuyumjian 1996).

4) The first deformational event $\left(D_{n}\right)$ resulted in vertical dips of sedimentary strata and geologic contacts, tight vertical folds and a pervasive schistosity (Sn). Metamorphic conditions that accompanied $D_{n}$ span greenschist to amphibolite facies. A dominant low pressure trend is indicated by amphibole exchange vectors and thermobarometric estimates.

Almeida, F F. M.; Hasui, Y.; Neves, B. B. B.; Fuck, R. A. 1981. Brazilian structural provinces: an introduction. Earth Sciences Reviews, 17:291-317.

Almeida, F. F. M. 1981.0 Craton do Paramirim e suas redoes com o do Sao Francisco. In: SBG, Simposio sobre o Craton do Sao Francisco e suas Faixas Marginais, Salvador, Anais, 1-9.

Barker, A. J. 1990. Introduction to Metamorphic Textures and Microstructures. 1 ed. Glasgow and London, Blakie \& Son Ltd. 161p.

Bebert, C. 0.1980. Complexo Basal Goiano. In: SBG, Congresso Brasileiro de Geologia, 31. Camburiu, Anais, 5:2837-2849.

Correia Filho, F. C. L.; Sa, A. M. 1980. Projeto Natividade. Goiania, DNPM/CPRM. 6 vol.

Costa, J. B. S. 1984. Aspestos litoestruturais e evolufdo crustal da regido centro-norte de Golds. Centre de Geociencias da Universidade Federal do Para, Belem, Tese de Doutoramento, 21 Op.

Costa, J. B. S.; Hasui, Y; Haralyi, N. L. E. 1991. The Central Brazil pop-up: an exemple of double ancient oblique continental collision. Tectonophysics, 191:412-413

Costa, L. A. M.; Portella, A. C. P.; Nilson, A. A.;Vale, C. R. O.; Marchetto, C. L. M.; Santos, E. L.; Meneguesso, G.; Inda, H. A. V.; Sterna, L. H.; Marchetto, M.; Baptista, M. B.; Fratin, O.; Mosmann, O.; Oliveira, T. F.; Silva, W. G. 1976. Projeto Leste Tocantins/Oeste do Sao Francisco. Rio de Janeiro, DNPM/CPRM/PROSPEC. 200p.

Cruz, E. L. C. C. da. 1993. Geologia e Mineralizacoes Aunferas do Terreno Granitoide-Greenstone de Almas-Dianopolis, Tocantins. Institute de Geociencias, Universidade de Brasilia, Brasilia, Disserta\$ao de Mestrado, 152p.

Cruz, E. L. C. C. da; Kuyumjian, R. M. 1993.0 embasamento daporfao norte da Faixa Brasilia na regiao de Almas-Dianopolis (TO) e seu contexto geodinamico durante o Brasiliano. In: SBG, Simposio sobre o Craton do Sao Francisco, 2,Salvador, Anais, 2-304.

Cruz, E. L. C. C. da; Kuyumjian, R. M. 1996. Chemical characterization of metabasalts and granitoids from the Almas-Dianopolis granite-greenstone terrane, Central Brazil. In: SBG, Symposium on Archaean Terranes of South American Platform, Brasilia, Extended abstracts, SBG, 53-54.

Danni, J. C. M.; Fuck, R. A.; Leonardos; O. H. 1982. Archean and lower proterozoic units in central Brazil. Geologische Rundschau, 71(1):291-317.

Hammarstrom, J. M.; Zen, E-an. 1986. Aluminum in hornblenda: an empirical igneous geobarometer. American Mineralogist, 71:1297-1313.
5) Emplacement of granitoid plutons was coeval with or later than Dn. The plutons may have been important in enhancing the metamorphic temperatures, but it is unlikely that they were important in driving greenstone belt deformation as diapiric domes. Contact relationships, deformation style of wall rocks, fabric development within granite-gneiss complexes and different source rocks illustrate a complex history of the construction of granite-gneiss terranes. They probably represent large multiplutonic complexes composed of several plutonic bodies which intruded the greenstone sequence, rather than diapiric domes.

6) The $D_{n+1}$ event resulted in dextral strike-slip shear zones. Deformation was restricted to the proximity of shear zones in granite-gneiss domains, while in greenstone belts a more penetrative mylonitic foliation $\left(S_{n+1}\right)$ partially obliterates $D_{n}$ structural features. Metamorphic conditions were those of epidote-amphibolite facies.

Acknowledgements This research was supported by Universidade de Brasilia and CNPq (first author M.Sc. scholarship $\left.n^{\circ} 134599 / 91-8\right)$. We are grateful to T. Liverton for comments on an earlier version of the manuscript and English revision. Thanks are due to MINERATINS company who funded the field logistic of this work. We also wish to thank the staff of Electron Microprobe Laboratory of Universidade de Brasilia, where mineral analyses were performed.

\section{References}

Hasui, Y.; Haralyi, N. L. E. 1985. A megaestruturacao de Goids. In: SBG, Simposio de Geologia do Centro-Oeste, 2, Goiania, Ata, 120-144.

Hasui, Y.; Tassinari; C. C. G.; Junior, O. S.; Teixeira, W. Almeida, F. F. M. de; Kawashita, K. 1980. Datacoes Rb-Sr e K-Ar no centro-norte do Brasil e seu significado geologico-geotectonico. In: SBG, Congresso Brasileiro de Geologia, 31, Camburiu, Anais, 5:2669-2676.

Holdaway, M. J.; Mukhopadhyay, B. 1993. A reevaluation of the stability relations of andalusite: thermochemical data and phase diagram for the aluminum silicates. American Mineralogist, 78:298-315.

Holland, T. J. B.; Powell, R. 1991. An enlarged and updated internally consistent thermodynamic dataset with uncertainties and correlations: the system $\mathrm{K}_{2} \mathrm{O}-\mathrm{Na}_{2} \mathrm{O}-\mathrm{CaO}-\mathrm{MgO}-\mathrm{MnO}-\mathrm{FeO}-\mathrm{Fe}_{2} \mathrm{O}_{3}-\mathrm{Al}_{2} \mathrm{O}_{3}-\mathrm{SiO}_{2}-\mathrm{C}-$ $\mathrm{H}_{2}-\mathrm{O}_{2}$. Journal of Metamorphic Geology, 8:89-124.

Johnson, M. C.; Rutherford, M. J. 1989. Experimental calibration of the aluminum-in-horblenda geobarometrer with application to Long Valley caldera (California) vulcanic rocks. Geology, 17:837-841.

Kister, A. F. M.; Anhaeusser, C. R. 1995. Emplacement features of Archean TTG plutons along the southern margin of the Barberton greenstone belt, South Africa Precambrian Research, 75:1-15.

Laird, J.; Albee, A. L. 1981. Pressure, temperature, and time indicator in mafic schists: their implications to reconstructing the polymetamorphic history of Vermont. American Journal of Science, 281:127-175.

Leake, B. E. 1978. Nomeclature of amphiboles. Miner. Petrogr. Acta, 22:195-224.

Maruyama, S.; Suzuke, K.; Liou, J. G. 1983. Greenschist-amphibolite transition equilibria at low pressures. Journal of Petrology, 24(4):583-604

Liou, J. G.; Kuniyoshi, S.; Ito, K. 1974. Experimental studies of the phase relations between greenschist and amphibolite in a basaltic system. Americam Journal of Science, 274:613-632.

Mengel, B. F.; Rivers, T. 1991. Decompression reactions and P-T conditions in high grade rocks, Northen Labrador: P-T-t path from individual samples and implications for early proterozoic tectonic evolution. Journal of Petrology, 32(1):139-167.

Miyashiro, A. 1913.Metamorphism and Metamorphic Belts. London, George Alien \& Unwin, 492p.

Padilha, J. L. 1984. Prospecção de ouro na regiao nordeste de Goids - Projeto Pindorama -DOCEGEO. In: Encontro Regional do Ouro de Goiás, 1, Goiania, Anais, 78-92.

Pimentel, M. M.; Fuck, R. A. 1987. Late proterozoic grantitic magmatism in southwestern Goias, Brazil. Revista Brasileira de Geociencias, 17(4):414-425. 
Pimentel, M. M.; Fuck, R. A.; Machado, N.; Fuck, R. F.; Ribeiro, K. R.; Viana, M. G. 1993. Dados geocronologicos U-Pb preliminares da regiao de Mara Rosa, Goias: implicafoes para a 6poca da mineraliza9ao de $\mathrm{Au}$ e para a evolucao tectonica neoproterozoica no centro-oeste. In: SBG, Congresso Brasileiro de Geoqufmica, 4, Anais, 255-258.

Powell. R.; Holland, T. J. B. 1988. An internally consistent thermodynamic dataset with uncertainties and correlations: 3 . applications to geobarometry, worked examples and computer program. Journal of Metamorphic Geology, 6:173-204.

Silva, A. da; Souza, L. H. de; Ferreira, M. C. B. 1990. Altera9ao hidrotermal da sequencia de rochas do alvo corrego Paiol e mineralizacao aurifera associada. In: SBG, Congresso brasileiro de geologia, 36, Natal, Anais, 3:1129-1143.

Shackleton, R. M. 1995. Tectonic evolution of greenstone belts. In: M. P. Coward e A. C. Ries (ed.) Early Precambrian Processes. Geological Society Special Publication N ${ }^{\circ}$ 95, 53-65.
Spear, F. S. 1981. An experimental study of horblende stability in amphibolite. American Journal of Earth Science, 281:697-734.

Tassinari, C. C. G.; Siga Junior, O.; Teixeira, W. 1981. Panorama geocronoldgico do centro-oeste brasileiro: solufoes, problematicas e sugestoes. In: SBG, Simpdsio de Geologia do Centro-oeste, 1, GoiSnia, Ata,93-114.

Thompson, J. B.; Laird, J.; Thompson, A. B. 1982. Reactions in amphibolite, greenschist and blueschist. Journal of Petrology, 23(1): 1-27.

Manuscrito A-983

Recebido em 24 de julho de 1997

Revisao dos autores em 05 de outubro de 1997

Revisao aceita em 10 de outubro de 1997 